\title{
MLL/GPHN Fusion Protein
}

National Cancer Institute

\section{Source}

National Cancer Institute. MLL/GPHN Fusion Protein. NCI Thesaurus. Code C99332.

A fusion protein encoded by the MLL/GPHN fusion gene. This protein is comprised of the $\mathrm{N}$-terminal half of the histone-lysine $\mathrm{N}$-methyltransferase MLL protein, including the AT hook DNA binding domain and the DNA methyltransferase domain, fused with the Cterminus of the gephyrin protein including the presumed tubulin-binding site and a domain homologous to the E. coli molybdenum cofactor biosynthesis protein. 